gardens, and that the germplasm of at least 100 species will be collected and conserved in the Germplasm Bank of Wild Species at Kunming Institute of Botany. A database will be developed to collect and store survey information, and after the completion of the programme these data will be shared on the National Infrastructure Platform of Science and Technology, to support conservation and research. In addition, a germplasm collecting and conserving standard for Plant Species with Extremely Small Populations will be developed. It is anticipated that this programme will not only help to conserve the target species, but will also help to improve scientific research and investigations of the economic values of these plants.

JING YANG Key Laboratory for Plant Diversity and Biogeography of East Asia, Kunming Institute of Botany, Chinese Academy of Sciences, Kunming, China

WEIBANG SuN Kunming Botanical Garden, Kunming Institute of Botany, Chinese Academy of Sciences, Kunming, China E-mailwbsun@mail.kib.ac.cn

\section{Poland: Central European large river ecosystems under unprecedented threat}

In 2016 the government of Poland adopted a development strategy for inland waterways, to adapt the country's rivers to the criteria of international standards for inland waterways, corresponding to at least navigability class IV. The Act relating to Poland's ratification of the European Agreement on Main Inland Waterways of International Importance came into force on 15 February 2017. The Act, even if only partially implemented, will pose a grave threat to the largest Central European rivers. The strategy's main aims include modifying river beds, drainage, dredging, and the construction of dams, reservoirs, levees and riverside revetments along the lengths of Poland's longest rivers. The strategy is only viable if the main rivers are converted into a series of canals by the construction of barrages. This would have a dramatic impact on pan-European environmental corridors and river ecosystems in Germany, the Czech Republic, Ukraine and Belarus.

Implementing the strategy in the Oder valley would undermine the integrity of the entire chain of protected areas along this river, including 17 Natura 2000 sites from the Czech border to the Baltic Sea. A preliminary analysis carried out by a team of scientists and NGO experts, led by the Naturalists' Club (www.kp.org.pl/pdf/stanowiska/ wodne/2016-09_Risk_influence_inl_waterways_develop_on_ nature.pdf), indicates that the project threatens some of the most valuable rivers in Europe, including associated riparian, ash-elm-oak forest, and large numbers of nesting and foraging sites of threatened species such as the white- tailed eagle Haliaeetus albicilla, black kite Milvus migrans, red kite Milvus milvus, black tern Chlidonias niger, corn crake Crex crex, middle spotted woodpecker Dendrocopos medius and others protected by the EU's Habitats and Birds Directives. Most of the unique oxbow ecosystem together with its plants and animals would disappear, including many localities of the floating water-plantain Luronium natans, northern crested newt Triturus cristatus, European fire-bellied toad Bombina bombina, yellow-bellied toad Bombina variegata, Eurasian otter Lutra lutra and Eurasian beaver Castor fiber. The estimated cost of the works on the $742 \mathrm{~km}$ of the Oder alone is USD 7.1 billion during the next 15 years.

In the Vistula valley the integrity of the 10 Natura 2000 areas and 10 nature reserves between Warsaw and the Baltic Sea would be damaged. Habitats for rare species of birds (e.g. the largest Polish breeding populations of common ringed plover Charadrius hiaticula, common gull Larus canus, sandwich tern Sterna sandvicensis, common tern Sterna hirundo and little tern Sternula albifrons) would be destroyed, as would sandbanks, the sole resting sites of the grey seal Halichoerus grypus in Poland. Barrage construction on both the Vistula and Oder would hamper the migration of diadromous fish, reducing access to their spawning grounds.

Important aspects of the strategy are canal connections with the Dniester and Danube basins. These would threaten Europe's freshwater ecosystems by facilitating migration of alien plant and animal species between basins.

The Polish government's strategy appears to contradict EU law, and contravenes the Habitats and Birds Directive and the Water Framework Directive. Nevertheless, some aspects of this strategy are to be financed by the European Investment Bank (part of the so-called Juncker Plan) and are being considered by the World Bank. The European Commission is, however, investigating whether the strategy's environmental impact has been properly assessed. In response to the threat posed by the strategy, more than 20 NGOs (including WWF Poland and BirdLife Poland) have formed a coalition under the name Koalicja Ratujmy Rzeki! (Save the rivers!; www.kp.org.pl/ index.php?option $=$ com_content $\&$ task $=$ view $\&$ id $=1173 \&$ Itemid=353).

ŁUKASZ ŁAWICKI West-Pomeranian Nature Society, Szczecin, Poland.E-mailizuza@interia.pl

\section{Pawee PawlaczyK Naturalist Club, Świebodzin, Poland}

KRZYSZTOF ŚWIERKOSZ Museum of Natural History, Wrocław University, Wrocław, Poland

ROMAN ŻUREK Institute of Nature Conservation, Polish Academy of Sciences, Kraków, Poland 